\title{
PROSES EMULSIFIKASI DAN PENGERINGAN PASTA CAMPURAN SUMBER ASAM FOLAT ALAMI DAN IDENSFIKASINYA DALAM PEROLEHAN SERBUK SUPLEMEN UNTUK WANITA HAMIL
}

\author{
Agustine Susilowati* Puspa Dewi Lotulung, Yati Maryati \\ Pusat Penelitian Kimia, Lembaga Ilmu Pengetahuan Indonesia, PUSPIPTEK, Serpong- 15314, Tangerang \\ Selatan-BANTEN. \\ *Corresponding author email: agustine_1408@yahoo.co.id
}

\begin{abstract}
Mixed powder of mung bean (Penaeus radiatus) tempeh, fermented broccoli (Brassica oleracea) and nixtamal of dent white corn (Zea mays identata) subsequently conducted through fermentation by Rhizopus oligosporus strain $C_{1}$, fermentation by Kombucha culture and nixtamalization by $\mathrm{Ca}(\mathrm{OH})_{2}$ were supplement novelty of natural folic acid for pregnant woman. Recovering folic acid as supplement was carried out through emulsification by adding gelatin at concentrations of 0, 1, 2, 3, 4 and $5 \%(w / w)$ and homogenizing at 0, 8000, 9500, 13500 and $20500 \mathrm{rpm}$ for 30 minutes, drying at $50{ }^{\circ} \mathrm{C}$ for 24 hours, and capsulation, respectively. The experimental result showed that rotation speed of homogenizer and gelatin concentration becoming more and more high would increase folic acid, dissolved protein and total solids, and decreased total sugars and reducing sugar till optimization followed by dropping supplement powder components were achieved. Based on the best folic acid, optimum treatment was reached for treatment combination between gelatin concentration of $3 \%(w / w)$ and homogenation rotation speed of 9500 rpm for 30 minutes. This condition produced supplement with compositions of folic acid $374.29 \mu \mathrm{g} / \mathrm{mL}$, dissolved protein $6.30 \mathrm{mg} / \mathrm{mL}$, total sugars $16.64 \mu \mathrm{g} / \mathrm{mL}$, reducing sugars $744.70 \mathrm{mg} / \mathrm{mL}$ and total solids $91.12 \%$. Identification of folic acid at mixed pasta was achieved 2 peaks of T1,9 and T 2,2 dominated by folic acid monomer with molecular weight $(\mathrm{MW})\left(\mathrm{M}^{+1}\right)$ of 442,68 and 442,95 Dalton (Da.) with relative intensities of 8,46 and 5,72\%, while at suplement powder was achieved 1 peaks of $T 2,1$ dominated by folic acid monomer with molecular weight of 442,62 with relative intensities of 4,2\%.
\end{abstract}

Keywords : Folic aacid, homogenization, gelatin, rotation speed, supplement.

\begin{abstract}
ABSTRAK
Serbuk campuran tempe kacang hijau (P. radiatus), brokoli (Brassica oleracea) terfermentasi dan nikstamal jagung putih jenis gigi kuda (Zea mays identata) masing-masing diperoleh melalui fermentasi oleh $R$. oligosporus strain $\mathrm{C}_{1}$, fermentasi oleh kultur kombucha dan nikstamalisasi menggunakan $\mathrm{Ca}(\mathrm{OH})_{2}$ adalah kekinian suplemen asam folat alami untuk wanita hamil. Perolehan asam folat sebagai suplemen dilakukan melalui emulsifikasi dengan homogenisasi pada kecepatan putar berturut-turut $0,8000,9500,13500$ dan $20500 \mathrm{rpm}$ selama 30 menit dengan penambahan gelatin pada konsentrasi berturut-turut 0, 1, 2, 3, 4 dan 5\% (b/b) selanjutnya dikeringkan selama 24 jam pada suhu $50^{\circ} \mathrm{C}$ dan kapsulasi. Hasil penelitian menunjukkan bahwa semakin tinggi kecepatan putar homogenizer dan konsentrasi gelatin, akan meningkatkan asam folat , protein terlarut dan total padatan namun menurunkan total gula dan gula reduksi sampai dicapai optimisasi diikuti penurunan komponen serbuk suplemen. Perlakuan optimum berdasarkan asam folat terbaik dicapai pada kombinasi perlakuan konsentrasi 3\% gelatin dengan kecepatan putar $9500 \mathrm{rpm}$ selama 30 menit yang menghasilkan suplemen dengan komposisi asam folat $374,29 \mu \mathrm{g} / \mathrm{mL}$, protein terlarut $6,30 \mathrm{mg} / \mathrm{mL}$, total gula $16.64 \mu \mathrm{g} / \mathrm{mL}$, gula reduksi $744,70 \mathrm{mg} / \mathrm{mL}$ dan total padatan $91,12 \%$. Identifikasi asam folat pada pasta campuran diperoleh 2 peak dengan waktu retensi masing-masing T 1,9 dan T 2,2. Mass spektra pada ke dua waktu retensi tersebut didominasi oleh monomer asam folat berberat molekul $\left(\mathrm{M}^{+1}\right)$ masing-masing 442,68 dan 442,95 Da. dengan intesitas relatif masing-masing 8,46 dan 5,72\%, sedangkan pada produk serbuk suplemen diperoleh 1 peak dengan waktu retensi $\mathrm{T}$ 2,1 dengan dominasi monomer asam folat berberat molekul 442,62 pada intensitas relatif $4,2 \%$.
\end{abstract}

Kata kunci : asam folat, homogenisasi, gelatin, kecepatan putar, suplemen.

Submitted on: 5 January 2017 Accepted on: 15 February 2017

DOI: https://.doi.org/10.25026/jsk.v1i9.70 


\section{PENDAHULUAN}

Proses emulsifikasi dan pengeringan pasta campuran tempe kacang hijau ( $P$. radiatus L), brokoli (Brassica oleracea) terfermentasi dan nikstamal jagung putih jenis gigi kuda (Zea mays identata) adalah suatu upaya untuk memperoleh serbuk campuran sumber asam folat alami. Asam folat (folic acid, folate, folacin, vitamin B9, pteroyl-L-glutamic acid, pteroyl-Lglutamate, pteroylmonoglutamic acid) penting bagi wanita hamil dan anak-anak pada masa pertumbuhan dan usia lanjut [1].

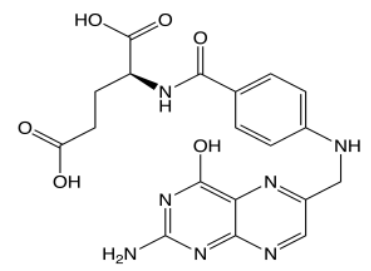

Gambar 1. Asam Folat

Peranannya sebagai precursor dalam sintesis nukleotid ke remetilasi homocysteine penting pada period pembelahan dan pertumbuhan sel terutama untuk memproduksi sel darah merah dan mencegah anemia [2], mencegah timbulnya kecacatan tabung saraf (Neural Tube Defects/ NTDs) pada bayi, yaitu spina bifida dan anencephaly

Dengan asupan asam folat yang cukup pada masa sebelum dan selama kehamilan yaitu sekitar $0.4-0.8 \mathrm{mg}$ per hari, risiko timbulnya NTDs pada bayi dapat diturunkan hingga $80 \%$ [3]. Untuk pencegahan terjadinya NTDs maupun cacat pada sistem saraf (otak), wanita yang berencana hamil perlu mengonsumsi asam folat secara cukup, minimal 4 bulan sebelum kehamilan.

Tempe kacang hijau (Phaseolus radiatus) hasil fermentasi Rhizopus oligosporus strain $\mathrm{C}_{1}$ diketahui berpotensi sebagai sumber asam folat, lebih baik dibandingkan dengan jenis tempe yang lain [4]. Aktifitas enzim protease Rhizopus oligosporus strain $\mathrm{C}_{1}$ dalam mendegradasi protein tempe diduga berpengaruh terhadap perolehan asam folat. Telah diketahui bahwa asam folat merupakan bagian dari protein terlarut oleh struktur kimianya yang terdiri dari PABA (para amino benzoat), asam glutamat dan pteridin [5]. Hal ini memungkinkan terjadinya perombakan komponen substrat (kacang hijau) selama fermentasi berlangsung dalam membentuk asam folat. Pada fermentasi brokoli oleh kultur kombucha, perombakan komponen keseluruhan dalam memperoleh asam folat diduga disebabkan aktifitas enzyme dihydrofolate synthase (DHFS) dan enzyme folypolyglutamate synthase (FPGS) masing-masing membentuk dihydrofolate dan polyglutamat folate, suatu bentuk derivate asam folate [6] dimana proses ini hanya terjadi pada tumbuhan dan mikroba [7]. Kultur kombucha mengandung bakteri asam asetat (Acetobacter xylinum), yeast ( $S$. cereviseae, S. ludwigii, S.bisporus, Zygosaccharomyces sp) dan beberapa jenis khamir (Torolupsis sp) [8], diduga dapat mendegradasi polifenol dan asamasam amino pada brokoli. Diketahui terdapat lebih dari 8 jenis enzim spesifik dari tanaman yang berperan dalam sintesis ini, terutama yang berperan melalui esterifikasi $\rho A B A$ dengan glucose [9]. Fermentasi ini adalah kekinian proses untuk memperoleh asam folat alami sebagai alternatif dari asam folat. Penggunaan jagung putih jenis gigi kuda (Zea mays identata) dengan proses modifikasi nikstamalisasi menggunakan $\mathrm{Ca}(\mathrm{OH})_{2}$ menjadi alternatif sumber energi selain sumber asam folat alami. Pada proses ini terjadi peningkatan asam folat pada kondisi optimum yang dilakukan untuk mempertahankan asam folat yang larut atau terbuang selama 
nikstamalisasi [10]. Pada nikstamalisasi konvensional, proses ini mempermudah gelatinisasi pati dan penyerapan air serta mengeluarkan sebagian lembaga dan perikarp dari bji jagung [11]. Suplemen asam folat alami yang diperoleh dari campuran tempe kacang hijau $(P$. radiatus, brokoli (Brassica oleracea) terfermentasi dan nikstamal jagung putih jenis gigi kuda (Zea mays identata) melalui proses emulsifikasi dengan gelatin pada kecepatan putar homogeniser dan konsentrasi gelatin yang berbeda dan selanjutnya dikeringkan akan menghasilkan serbuk suplemen dengan karateristik yang spesifik terutama komposisi dan dominasi monomer asam folat melalui LCMS. Tujuan penelitian ini adalah untuk mengetahui kondisi proses emulsifikasi terbaik pasta campuran melalui perbedaan konsentrasi gelatin dan kecepatan putar homogeniser dan hubungannya dengan proses pengeringan terhadap karateristik serbuk suplemen asam folat alami.

\section{METODOLOGI}

\section{Bahan dan Peralatan}

Bahan utama dalam penelitian ini adalah kacang hijau dan brokoli dari pasar setempat; kultur Rhizopus oligosporus strain $\mathrm{C}_{1}$ dan kultur kombucha dari Pusat Penelitian KimiaLIPI ; jagung putih jenis gigi kuda (Zea mays identata) dari sentra perkebunan setempat, sukrosa, gelatin dan bahanbahan kimia untuk proses dan analisis. Peralatan proses yang digunakan adalah peralatan mikrobiologi yaitu sistem laminar flow, lemari fermentasi, incubator; peralatan nikstamalisasi; blender dan homogenizer (Turax, Germany). Instrumen analisis utama adalah spektrofotometer (UV), LC-MS (Mariner Biospectrometry) dengan LC
(Hitachi L 6200) dan microfiltrasi sel berpengaduk (Amicon) menggunakan membran mikrofitrasi $0,15 \mu \mathrm{m}$.

\section{Rancangan Penelitian}

Penelitian dilakukan dengan melakukan fermentasi kacang hijau menggunakan inokulum Rhizopus oligosporus strain $\mathrm{C}_{1}$, fermentasi brokoli menggunakan inokulum brokoli dari kultur (stok) kombucha dan proses nikstamalisasi jagung putih jenis gigi kuda (Zea mays identata) [12], pencampuran dan homogenisasi pada kecepatan putar berturut-turut 0,8000, 9500, 13500 dan $20500 \mathrm{rpm}$ selama 30 menit dengan penambahan gelatin pada konsentrasi berturut-turut $0,1,2,3,4$ dan $5 \%$ (b/b), pengeringan selama 24 jam pada suhu $50^{\circ} \mathrm{C}$, pengecilan ukuran dan kapsulasi.

Analisis dilakukan terhadap protein terlarut (metode Lowry) [13, total padatan (metode Gravimetri), gula reduksi (Somogyi-Nelson), total gula (metode Fenol Sulfat) [14] dan asam folat (spektrofotometri UV-VIS) [15]. Identifikasi monomer asam folat dan asam glutamat dilakukan melalui LC-MS (Mariner Biospectrometry) dengan LC (Hitachi L 6200) [16].

\section{Tahapan proses}

\section{Proses fermentasi kacang hijau (tempe)}

Sejumlah kacang hijau ( $P$. radiatus) disortasi, dicuci bersih, direbus selama 30-45 menit selanjutnya didinginkan, direndam dalam air semalam pada $\mathrm{pH} 5$. Keesokannya dikupas, dicuci bersih, ditiriskan dan diinokulasi dengan inokulum Rhizopus oligosporus strain $\mathrm{C}_{1}$ pada konsentrasi $0,2 \%(\mathrm{~b} / \mathrm{b})$ merata, dibungkus dalam plastik berlubang dan diinkubasi selama 24-36 jam pada suhu ruang $\left(28-30^{\circ} \mathrm{C}\right)$ sampai terlihat miselia memenuhi permukaan kacang. 
Proses fermentasi brokoli.

Dilakukan blansing pada brokoli selama 5 menit pada suhu $80{ }^{\circ} \mathrm{C}$, selanjutnya dilumatkan pada rasio 1 bagian brokoli dan 4 bagian air sehingga diperoleh bubur dan difiltrasi lolos 60 mesh. Filtrat (suspensi) adalah substrat selanjutnya dibubuhi dengan inokulum brokoli [12] sebanyak $15 \%$ (v/b suspensi brokoli) dan sukrosa $10 \%$ (b/b bubur brokoli) selanjutnya disimpan pada wadah tertutup dengan aerasi (kain kassa) pada ruang gelap dan suhu ruang (28$30^{\circ} \mathrm{C}$ ) selama 3 hari. Seluruh pekerjaan dilakukan secara aseptis. Perolehan biomasa adalah suspensi brokoli terfermentasi.

\section{Proses nikstamalisasi jagung}

Sejumlah jagung putih jenis gigi kuda (Zea mays identata) dicuci, direndam dalam air dengan perbandingan 1 bagian jagung dengan 4 bagian air. Pada rendaman jagung putih selanjutnya dibubuhkan $\mathrm{Ca}(\mathrm{OH})_{2} 30 \%$ (b/b protein terlarut jagung) dan direbus selama 30 menit pada suhu $90^{\circ} \mathrm{C}$, didinginkan, dicuci untuk menghilangkan sisa alkali dan ditiriskan. Biji jagung (nikstamal) selanjutnya digrinder / digiling dan diayak lolos 60 mesh sehingga dihasilkan nikstamal jagung siap digunakan.

\section{Proses pencampuran \& emulsifikasi pasta fortifikan.}

Proses pencampuran awal dilakukan terhadap tempe kacang hijau dan brokoli terfermentasi pada rasio 1:1 [12] selanjutnya dihomogenisasi pada kecepatan putar $8000 \mathrm{rpm}$ selama 30 menit sehingga dihasilkan pasta campuran tempe \& brokoli fermentasi. Selanjutnya dibubuhkan nikstamal jagung ( 5 bagian), dan gelatin pada konsentrasi $1 \%$ dan homogenisasi dilakukan kembali pada kecepatan putar $8000 \mathrm{rpm}$ selama 30 menit sampai diperoleh pasta campuran tempe kacang hijau, brokoli terfermentasi dan nikstamal jagung putih kemudian dikeringkan pada pengering kabinet pada suhu $50^{\circ} \mathrm{C}$ selama 24 jam dan pengecilan ukuran partikel (grinder), pengayakan lolos 60-80 mesh. Perolehan serbuk adalah bahan suplemen untuk asam folat alami. Proses yag sama dilakukan dengan kombinasi perlakuan sesuai rancangan penelitian. Kontrol dilakukan terhadap perlakuan tanpa penambahan gelatin (0\%), dengan homogenisasi $4000 \mathrm{rpm}$ selama >10 detik atau diasumsikan sebagai $0 \mathrm{rpm}$. Gambar 2 memperlihatkan skema proses keseluruhan pembuatan serbuk suplemen asam folat alami.

\section{HASIL DAN PEMBAHASAN}

\section{(1) Karateristik bahan.}

Bahan utama dalam pembuatan suplemen asam folat alami terdiri dari campuran tempe k. hijau, brokoli terfermentasi dan nikstamal jagung masing-masing adalah hasil fermentasi menggunakan inokulum $R$. oligosporus $\mathrm{C}_{1}$, kultur kombucha dan nikstamalisasi menggunakan $\mathrm{Ca}(\mathrm{OH})_{2}$. Komposisi ke tiga jenis bahan ditunjukkan pada Tabel 1, sedangkan Gambar 3a, 3b dan 3c berturut-turut memperlihat ke tiga jenis bahan awal. 


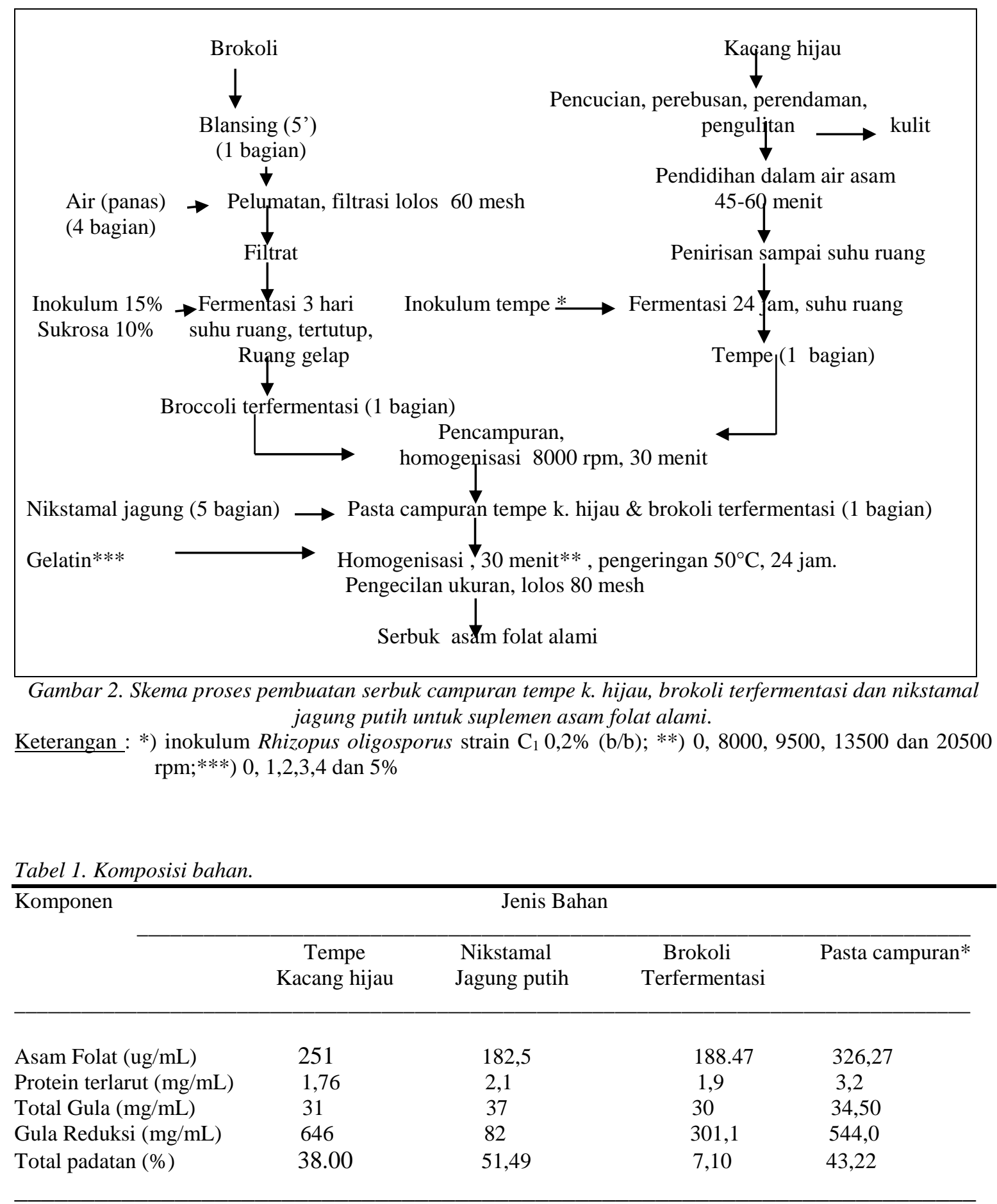

Keterangan :*) pada rasio tempe k. hijau, brokoli terfermentasi dan nikstamal jagung putih 1:1:5.

Tempe k. hijau menghasilkan asam folat terbaik $(251 \mathrm{ug} / \mathrm{mL})$, lebih tinggi dibandingkan dengan brokoli terfermentasi $(188.47 \mathrm{ug} / \mathrm{mL})$ maupun nikstamal jagung $(182,5 \mathrm{ug} / \mathrm{mL})$. Pada proses fermentasi kacang hijau peningkatan asam folat terjadi sebesar $120,17 \%$ atau 1,2 kali dibandingkan dengan sebelum fermentasi $(114 \mu \mathrm{g} / \mathrm{mL})$ [4]. Diduga hal ini disebabkan oleh 
aktifitas spesifik protease dalam mendegradasi protein menjadi asam-asam amino terutama asam glutamat [17]. Diketahui bahwa asam folat $\left(\mathrm{C}_{19} \mathrm{H}_{19} \mathrm{~N}_{7} \mathrm{O}_{6}\right.$, berat molekul 441 Da. $)$ memiliki struktur kimia terdiri dari 3 gugus yaitu pteridin, para aminobenzoic acid/PABA dan asam glutamat $[3,18]$. Ketiga gugus tersebut tersebut mengandung atom nitrogen dimana keberadaan asam glutamat menjadi indikasi utama sebagai asam folat. Hal ini menyebabkan keberadaan asam folat dimungkinkan berbanding lurus dengan konsentrasi protein terlarut dan N-Amino. Hal yang sama juga tampak pada proses nikstamalisasi jagung dimana terjadi peningkatan asam folat sebesar 94,44\% dari sebelum $(93.86 \mu \mathrm{g} / \mathrm{mL})$ dan sesudah nikstamalisasi $(182,5 \mu \mathrm{g} / \mathrm{mL})$ yang diduga disebabkan interaksi antara konsentrasi $\mathrm{Ca}(\mathrm{OH})_{2} \quad(20 \%)$ dengan waktu perebusan (30 menit). Absorbsi asam folat oleh $\mathrm{Ca}(\mathrm{OH})_{2}$ yang didukung proses perebusan menyebabkan terjadinya pengikatan asam folat pada nikstamal jagung [10]. Kecenderungan yang sama tampak pada proses fermentasi brokoli yang meningkatkan asam folat sebesar $115,39 \%$ atau 1,15 kali dibandingkan sebelum fermentasi $(87,5 \mu \mathrm{g} / \mathrm{mL})$ [19] menjadi $188.47 \mu \mathrm{g} / \mathrm{mL}$ pada kondisi proses optimum. Peningkatan ini diduga diesebabkan aktifitas enzyme dihydrofolate synthase (DHFS) dan enzyme folypolyglutamate synthase (FPGS) baik pada kultur kombucha maupun brokoli membentuk dihydrofolate dan polyglutamat folate, suatu bentuk derivate asam folate [6].

Komponen penting lainnya adalah gula reduksi yang menjadi indikator proses fermentasi dimana degradasi sukrosa pada brokoli terfermentasi, hidrolisis enzim amylase pada fermentasi kacang hijau dan pengikatan $\mathrm{Ca}(\mathrm{OH})_{2}$ pada jagung menghasilkan gula-gula sederhana masing-masing sebesar 646, 82 dan $30,11 \mathrm{mg} / \mathrm{mL}$ yang berpotensi sebagai sumber energi pada suplemen. Terhadap protein terlarut, total gula dan total solid ke tiga jenis bahan masingmasing mengindikasikan aktifitas enzim (protease, amylase) inokulum R.oligosporus strain $\mathrm{C}_{1}$ dan kultur kombucha masing-masing untuk tempe kacang hijau dan brokoli terfermentasi dan kondisi proses nikstamalisasi pada jagung. Pada proses pencampuran ke tiga komoditas terjadi perbedaan komposisi yang dipengaruhi oleh rasio bahan dan proses homogenisasi.

\section{(2). Pengaruh proses emulsifikasi dan pengeringan terhadap komposisi serbuk suplemen asam folat.}

Proses emulsifikasi dengan perbedaan kecepatan putar homogenizer dan konsentrasi gelatin yang selanjutnya di keringkan melalui pengering kabinet pada suhu $50^{\circ} \mathrm{C}$ selama 24 jam menghasilkan serbuk suplemen.

\section{Asam folat $(\mu \mathrm{g} / \mathrm{mL})$, Protein terlarut $(\mathrm{mg} / \mathrm{mL})$ dan Total Padatan $(\%)$}

Asam folat (pteroyl-L-glutamic acid, pteroyl-L-glutamate, pteroylmonoglutamic acid)dan protein terlarut adalah satu kesatuan dimana asam folat merupakan derivat protein terlarut. Hal ini disebabkan struktur asam folat terdiri dari PABA (para amino benzoat), asam glutamat dan pteridin [3]. Keberadaan asam glutamat menjadikan asam folat memiliki sifat fisik hampir sama dengan asam-asam amino lainya terhitung sebagai protein terlarut menurut metode Lowry [13]. Terhadap asam folat, penambahan gelatin meningkatkan asam folat sejalan dengan kecepatan putar homogenizer sampai dicapai kondisi optimum $(374,29 \mu \mathrm{g} / \mathrm{mL}) \quad$ pada konsentrasi gelatin 3\% dengan kecepatan putar $9500 \mathrm{rpm}$ seperti ditunjukkan pada 
Gambar 4a. Peningkatan ini diduga disebabkan oleh semakin tingginya kecepatan putar sehingga terjadi pengecilan ukuran partikel oleh benturan dari gaya dorong/tekanan pengaduk. Pada ukuran partikel yang lebih rendah, dimungkinkan tegangan permukaan yang lebih besar sehingga meningkatkan adsorbsi asam folat. Pada konsentrasi gelatin yang lebih tinggi (5\%) dengan kecepatan putar yang sama, sistem emulsifikasi diduga tidak mampu menahan absorbsi asam folat atau terjadinya lisis asam folat oleh faktorfaktor interen sehingga menurunkan asam folat. Asam folat bersifat tidak stabil terhadap panas, tekanan dan cahaya sehingga perlakuan proses berpengaruh terhadap perolehannya $[1 ; 20 ; 21]$. Dibandingkan dengan perlakuan kontrol yaitu gelatin $0 \%$, kecepatan putar $0 \mathrm{rpm}$, perlakuan optimum ini meningkatkan asam folat sebesar 56,16 \% dari 239,68 $\mu \mathrm{g} / \mathrm{mL} \quad$ menjadi $374,29 \mu \mathrm{g} / \mathrm{mL}$. Kecenderungan yang hampir sama tampak pada protein terlarut meskipun pada kecepatan putar 20500 rpm dengan gelatin 5\% mulai terjadi penurunan protein terlarut seperti ditunjukkan pada Gambar 4b. Optimisasi berdasarkan protein terlarut serbuk suplemen dicapai pada kombinasi perlakuan kecepatan putar $20500 \mathrm{rpm}$ dengan gelatin 5\% yang menghasilkan protein terlarut sebesar $7.88 \mathrm{mg} / \mathrm{mL}$. Peningkatan ini disebabkan oleh kontribusi gelatin sumber protein (colagen) sehingga proses emulsifikasi akan melarutkan protein keseluruhan baik dari gelatin maupun bahan keseluruhan. Dibandingkan dengan perlakuan kontrol yaitu gelatin $0 \%$, kecepatan putar $0 \mathrm{rpm}$, perlakuan optimum (kecepatan putar 13500, gelatin 5\%) ini meningkatkan protein terlarut sebesar $16 \%$ dari 6,8 $\mathrm{mg} / \mathrm{mL}$ menjadi $7,88 \mathrm{mg} / \mathrm{mL}$.

\section{Total gula $(\mathrm{mg} / \mathrm{mL})$ dan Gula reduksi $(\mathrm{mg} / \mathrm{mL})$}

Total gula dan gula reduksi adalah komponen keseluruhan karbohidrat pada serbuk suplemen yang berasal dari campuran tempe, brokoli terfermentasi dan nikstamal jagung. Ke dua komponen ini merupakan sumber energi pada produk suplemen selain dari komponen utama asam folat alami. Terhadap total gula, interaksi perlakuan kecepatan putar dan konsentrasi gelatin menurunkan total gula serbuk suplemen seperti ditunjukkan pada Gambar 5a.
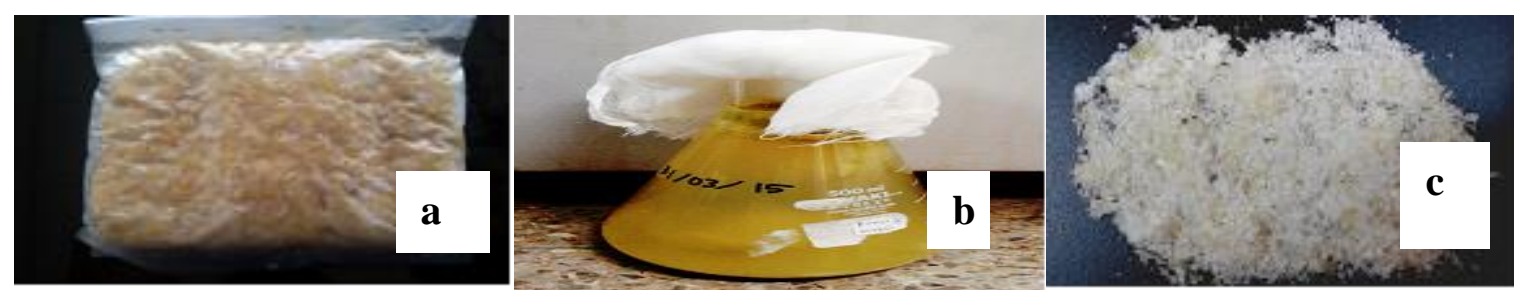

Gambar 3. (a) tempe kacang hijau, (b) brokoli terfermentasi dan (c) nikstamal jagung putih (Zea mays identata). 

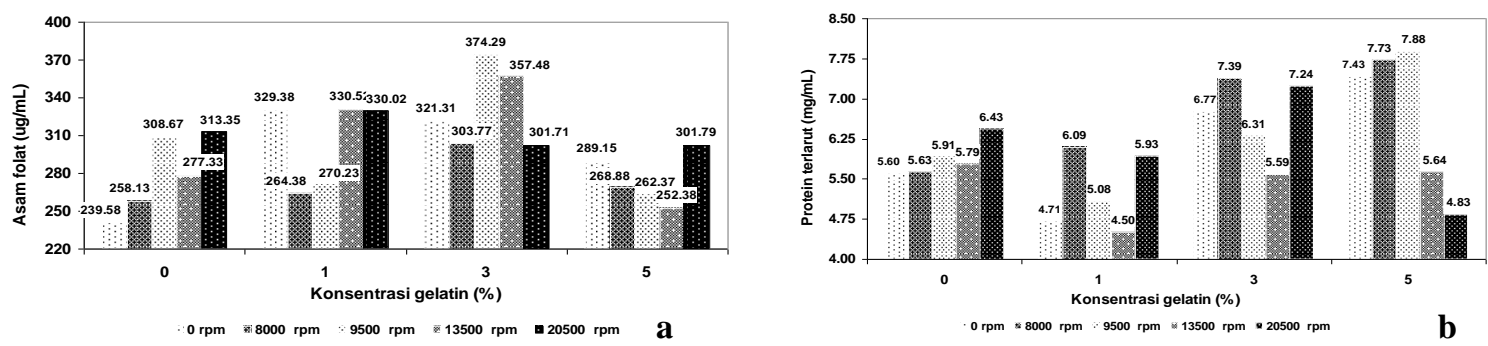

Gambar 4. Hubungan antara konsentrasi gelatin dengan kecepatan putar homogenisasi terhadap (a) asam folat dan (b) protein terlarut serbuk suplemen untuk wanita hamil.
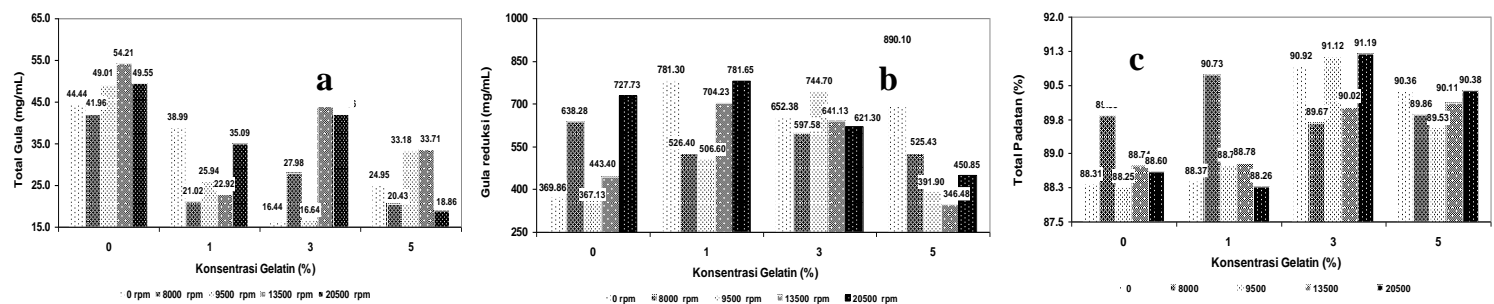

Gambar 5. Hubungan antara konsentrasi gelatin dengan kecepatan putar homogenisasi terhadap (a) total gula dan (b) gula reduksi dan (c) total padatan serbuk suplemen untuk wanita hamil.

Optimisasi proses terhadap total gula dicapai pada perlakuan tanpa pembubuhan gelatin (0\%) dengan kecepatan putar $13500 \mathrm{rpm}$ yang menghasilkan total gula sebesar 54.21 $\mathrm{ug} / \mathrm{mL}$ Penurunan total gula diduga terjadi disebabkan proses pengeringan yang memungkinkan terjadinya perubahan struktur kimia komponen. Kemungkinan terbentuknya pigmen coklat melanoidin seperti pada umumnya reaksi Maillard yaitu reaksi antara gula dan protein (gelatin dan pasta campuran) menyebabkan terjadinya karamelisasi [5; 22] sehingga tidak terdeteksi sebagai gula menurut metode Fenol Sulfat [14]. Dibandingkan dengan perlakuan kontrol yaitu gelatin $0 \%$, kecepatan putar $0 \mathrm{rpm}$, perlakuan optimum (kecepatan putar 13500, gelatin 0\%) ini meningkatkan total gula sebesar 21,98 \% dari 44.44 $\mathrm{mg} / \mathrm{mL}$ menjadi $54.21 \mathrm{mg} / \mathrm{mL}$. Te rhadap gula reduksi, interaksi perlakuan kecepatan putar dan konsentrasi gelatin cenderung menghasilkan gula reduksi yang berfluktuatif pada serbuk suplemen seperti ditunjukkan pada Gambar 5b. Optimisasi dicapai pada kecepatan putar 0 rpm dengan gelatin 5\% yang menghasilkan gula reduksi sebesar $890,10 \mathrm{mg} / \mathrm{mL}$. Peningkatan gula reduksi diduga disebabkan tidak adanya homogenisasi sehingga tidak menyebabkan lisisnya gula sehingga konsentrasinya semakin meningkat sejalan dengan peningkatan konsentrasi gelatin. Sistem pengikatan komponen melalui emulsifikasi ini menyebabkan bahan menjadi lebih kompak sehingga pada sistem pengeringan akan diperoleh gula reduksi serbuk suplemen yang lebih pekat menurut metode Nelson Somogyi [14]. Dibandingkan dengan perlakuan kontrol yaitu gelatin $0 \%$, kecepatan putar $0 \mathrm{rpm}$, perlakuan optimum (kecepatan putar $0 \mathrm{rpm}$, gelatin 5\%) ini meningkatkan gula reduksi sebesar $140,66 \%$ atau 1,46 kali dari 369.86 
$\mathrm{mg} / \mathrm{mL} \quad$ menjadi $\quad 890.10 \quad \mathrm{mg} / \mathrm{mL}$. Terhadap padatan kering, proses emulsifikasi dan selanjutnya pengeringan menghasilkan serbuk suplemen dengan total padatan yang semakin meningkat sampai tercapai optimisasi seperti ditunjukkan pada Gambar 5c. Padatan kering merupakan akumulasi dari seluruh komponen baik terlarut maupun tak larut dalam air. Peningkatan total solid diduga lebih disebabkan kontribusi gelatin sampai pada konsentrasi 3\%, namun pada konsentrasi $5 \%$ terjadi penurunan total solid pada beberapa perlakuan yang diduga disebabkan terjadinya denaturasi, lisis atau pelarutan bahan. Total padatan menjadi acuan dalam serbuk suplemen karena akan berpengaruh terhadap keseluruhan produk terutama untuk masa simpan, perhitungan berat suplemen per kapsul, penampilan dan keseluruhan komposisi produk suplemen. Optimisasi proses dicapai pada kecepatan putar 20500 , gelatin $3 \%$ dengan total padatan sebesar 91,19\%. Dibandingkan dengan perlakuan kontrol yaitu gelatin $0 \%$, kecepatan putar $0 \mathrm{rpm}$, perlakuan optimum ini meningkatkan total padatan sebesar 3,26\% dari $88.31 \%$ menjadi $91,19 \%$.

Dari telaah diketahui bahwa berdasarkan perolehan asam folat tertinggi, optimisasi proses dicapai pada perlakuan kecepatan putar homogenisasi $9500 \mathrm{rpm}$, pada konsentrasi gelatin 3\% yang menghasilkan asam folat sebesar 374, $29 \mathrm{ug} / \mathrm{mL}$. Gambar 6a, 6b dan 6c berturut-turut memperlihatkan pasta, serbuk dan suplemen asam folat alami untuk wanita hamil.

\section{Idensifikasi Asam folat}

Idensifikasi monomer asam folat dilakukan melalui LCMS pada contoh dari proses (pasta) dan sesudah proses (serbuk) dari perlakuan kecepatan putar homogenisasi $9500 \mathrm{rpm}, \quad$ pada konsentrasi gelatin 3\% yang beracu pada standar asam folat .

\section{Standar standar asam folat.}

Idensifikasi monomer pada standar asam folat diperoleh 1 peak kromatogram dengan waktu retensi $0-5$ menit yaitu T 1.6 dengan relatif intensitas $100 \%$ seperti yang ditunjukkan pada Gambar 7a, sedangkan mass spektranya ditunjukkan pada Gambar 7b.

Mass spektra standar asam folat pada 99-1200 mz menunjukkan dominasi senyawa dengan berat molekul 442.44 Da. Asam folat diketahui berberat molekul 441 Da. [5]. Berdasarkan LCMS diketahui bahwa dimungkinkan suatu senyawa memperlihatkan perbedaan BM dimana kemungkinannya adalah sebagai $\mathrm{M}^{+}, \mathrm{M}+\mathrm{Na}^{+}, 2 \mathrm{M}^{++}$atau $2 \mathrm{M}^{+}+\mathrm{Na}^{+}$. Hal ini disebabkan oleh adanya ionisasi karena sensitifitas instrumen LC-MS yang berkaitan dengan eluent yang digunakan. Kondisi operasi LC-MS adalah pada volume injeksi $5 \mu \mathrm{L}$, laju alir $0.1 \mathrm{~mL} /$ menit dengan eluent campuran Metanol dan Air pada rasio $80: 20$, menggunakan kolom C-8 (15 mm x 2 $\mathrm{mm})$ [16].

\section{Pasta campuran.}

Identifikasi asam folat pada pasta campuran dari proses terbaik $(9500 \mathrm{rpm}$, gelatin 3\%). Contoh sebanyak $2 \mathrm{mg}$ ditambahkan $950 \mu \mathrm{l}$ methanol $100 \%$, ditambahkan $\mathrm{NH}_{4} \mathrm{OH} 1 \%$ sebanyak $50 \mu \mathrm{l}$ diaduk dengan vortex dan disentrifugasi. Filtrat disaring dengan saringan $0.45 \mu \mathrm{m}$, filrat siap diinjeksi pada sistem LCMS. Analisis LCMS dikondisikan dengan menggunakan eluen campuran campuran $80 \%$ metanol dan $20 \%$ air masingmasing mengandung Asam Asetat $\left(\mathrm{CH}_{3} \mathrm{COOH}\right) \quad 0,3 \%$ sebagai pengion. Contoh sebanyak $5 \mu$ diinjeksikan pada alat LCMS dengan flow rate 0,1 $\mathrm{mL} /$ menit dengan eluent campuran 
Metanol dan Air pada rasio $80: 20$, menggunakan kolom C-8 (15 mm x 2 mm) [16]. Hasil identifikasi menghasilkan kromatogram dengan 2 jenis peak sebagai $\mathrm{T} 1,9$ dan $\mathrm{T} 2,2$ seperti ditunjukkan pada Gambar 7a, sedangkan mass spektra masing-masing peak ditunjukkan pada Gambar $7 \mathrm{~b}$ dan $7 \mathrm{c}$.
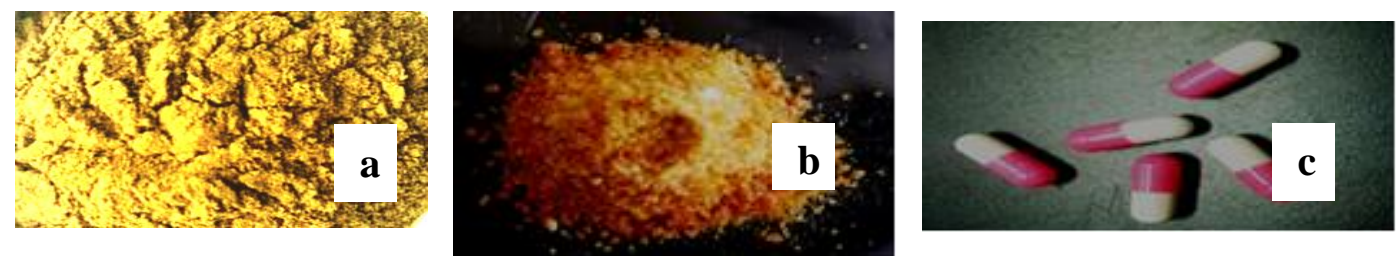

Gambar 6. (a) pasta, (b) serbuk dan (c) suplemen asam folat alami dari campuran tempe, brokoli terfermentasi dan nikstamal jagung dengan pengemulsi gelatin untuk wanita hamil.
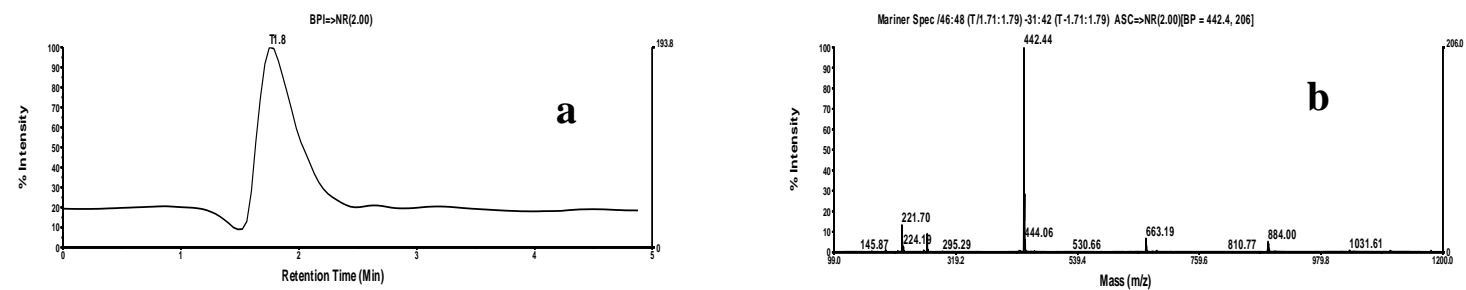

Gambar 7. (a) Kromatogram standar asam folat dengan T 1,6, (b) mass spektra standar asam asam folat dengan T 1.6 antara $99-1200 \mathrm{~m} / \mathrm{z}$.
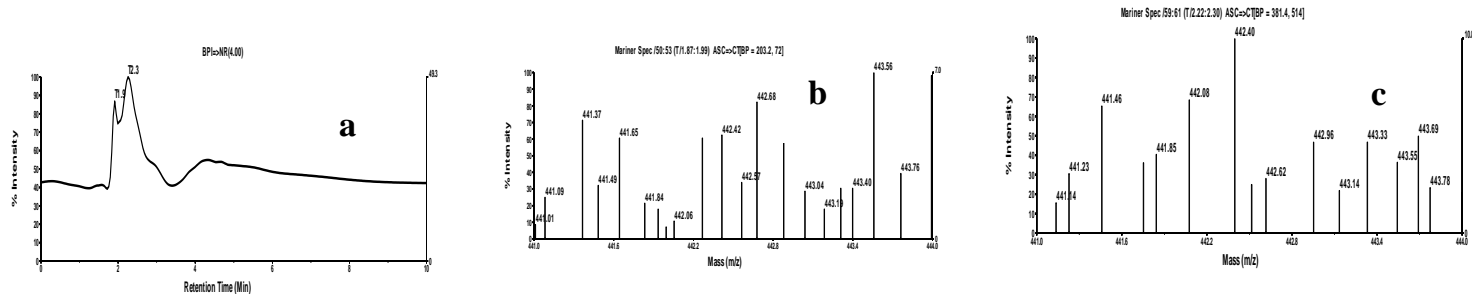

Gambar 7. (a) Kromatogram monomer asam folat dengan waktu retensi antara 0-10 menit, (b) Mass spectra dari T 1,9 dan (c) T 2, 2 antara 441-444 m/z dari pasta campuran pada perlakuan kecepatan putar homogenisasi 9500 rpm, konsentrasi gelatin 3\%) sebelum proses pengeringan.

Dari mass spektra T 1,19 ditemukan senyawa 14 monomer identik sebagai asam folat dengan berat molekul antara 441,01 sampai dengan 443,76 Da., intensitas relatif antara 2,41 sampai dengan $6,65 \%$. Dominasi monomer asam folat diperoleh pada monomer berberat molekul 442,68 Da. $\left(\mathrm{M}^{+1}\right)$ dengan intesitas relatif $8,46 \%$. Sedangkan pada
T 2,2 ditemukan 18 senyawa identik sebagai asam folat dengan berat molekul antara 441.14 sampai dengan $443.78 \mathrm{Da}$. dengan intensitas relatif antara 2.29 sampai dengan 5.72\%. Dominasi monomer asam folat diperoleh pada monomer berberat molekul 442.9557 Da. dengan intesitas relatif $5.72 \%$. 


\section{Serbuk suplemen}

Identifikasi asam folat pada serbuk suplemen yaitu pasta campuran hasil emulsifikasi yang telah dikeringkan dilakukan dengan metode yang sama dengan pasta campuran. Hasil identifikasi menghasilkan kromatogram dengan 2 jenis peak sebagai $\mathrm{T} 1,9$ dan $\mathrm{T}$ 2,2 seperti ditunjukkan pada Gambar 8a, sedangkan mass spektra ditunjukkan pada Gambar 8b.
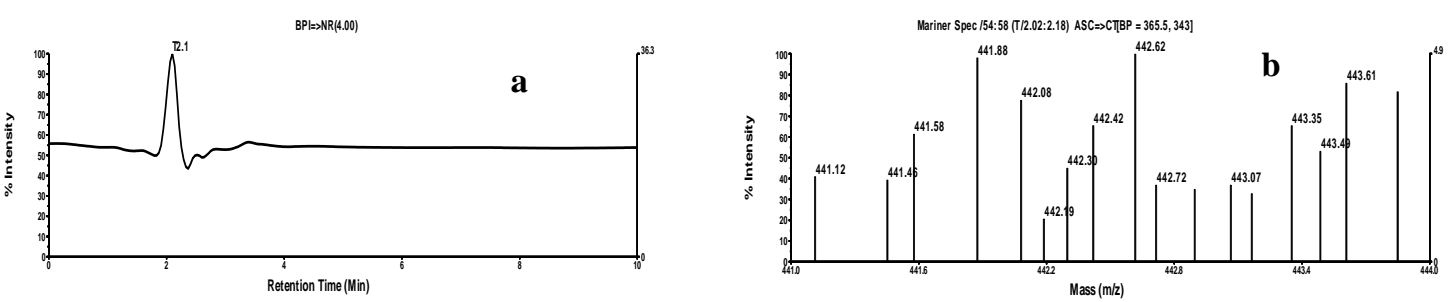

Gambar 8. (a) Kromatogram monomer asam folat dengan waktu retensi antara 0-10 menit , (b) Mass spectra dari T 2, 1 antara 441-444 m/z dari serbuk suplemen dari perlakuan dengan kecepatan putar homogenisasi 9500 rpm, konsentrasi gelatin 3\%).

Dari mass spektra $\mathrm{T}$ 2,21 ditemukan senyawa 17 monomer identik sebagai asam folat dengan berat molekul antara 441,116 sampai dengan 443,85 Da., intensitas relatif antara 1.58 sampai dengan $6.3 \%$. Dominasi monomer asam folat diperoleh pada monomer berberat molekul 442.62 Da. $\left(\mathrm{M}^{+1}\right)$ dengan intesitas relatif $4.2 \%$. Dari telaah idensifikasi monomer asam folat pada ke dua jenis contoh secara keseluruhan diketahui bahwa asam folat lebih terakumulasi pada pasta dibandingkan dengan serbuk kering.

\section{KESIMPULAN}

Hasil penelitian menunjukkan bahwa optimisasi kondisi proses terbaik Hasil penelitian menunjukkan bahwa semakin tinggi kecepatan putar homogenizer dan konsentrasi gelatin, akan meningkatkan asam folat, protein terlarut dan total padatan namun menurunkan total gula dan gula reduksi sampai dicapai optimisasi diikuti penurunan komponen serbuk suplemen. Pada masing-masing optimisasi asam folat, protein terlarut, total padatan, total gula dan gula reduksi terjadi peningkatan komponen berturut-turut sebesar 56,16, $16,3,26,21,98$ dan $140,66 \%$ atau 1,46 kali dibandingkan dengan konsentrasi masing-masing komponen pada perlakuan tanpa pembubuhan gelatin dan tanpa homogenisasi. Perlakuan optimum berdasarkan asam folat terbaik dicapai pada kombinasi perlakuan gelatin 3\% dengan kecepatan putar $9500 \mathrm{rpm}$ selama 30 menit yang menghasilkan serbuk suplemen dengan komposisi asam folat $374,29 \mu \mathrm{g} / \mathrm{mL}$, protein terlarut 6.30 $\mathrm{mg} / \mathrm{mL}$, total gula $16.64 \mu \mathrm{g} / \mathrm{mL}$, gula reduksi $744.70 \mathrm{mg} / \mathrm{mL}$ dan total padatan 91,12\%. Identifikasi asam folat pada pasta campuran diperoleh 2 peak dengan waktu retensi masing-masing T 1,9 dan T 2,2 . Mass spektra pada ke dua waktu retensi tersebut didominasi oleh monomer asam folat berberat molekul $\left(\mathrm{M}^{+1}\right)$ masing-masing 442,68 dan 442,95 Da. dengan intesitas relatif masingmasing 8,46 dan $5,72 \%$, sedangkan pada produk serbuk suplemen diperoleh 1 peak dengan waktu retensi $\mathrm{T} 2,1$ dengan dominasi monomer asam folat berberat molekul 442,62 pada intensitas relatif $4,2 \%$. 


\section{DAFTAR PUSTAKA}

[1]. Ural \& Serdar. 2008. Folic Acid and Pregnancy, Kid's Health. Diakses 2009-0319.

[2]. Anonymus. 2012a. Dietary Supplement Fact Sheet: Folate, Office of Dietary Supplements, National Institutes of Health. http://ods.od.nih.gov/factsheets/folate.asp, Diakses 8 December 2014.

[3]. Anonymous. 2012b. Folic acid, Semolus. Diakses 8 December 2014.

[4]. Susilowati, A., Aspiyanto, Lotulung, P.D., Maryati,Y. 2017a. Modification process in nixtamalization of folic acid-rich dent corn (Zea mays identata) and its identification as smart food fortificant. Proceedings of the 3 rd International Symposium on Applied Chemistry 2017, AIP Conference Proceedings, Volume 1904, AIP Publishing, Melville, New York, 2017, ISBN 978-07354-1594-2, ISSN, 0094-243X, Jakarta, Indonesia, 23-24 October 2017.

[5]. Belitz \& Grosch. 2002. Food Chemistry, 2nd edition Springer-Verlag Berlin Heidelberg. ISBN 3-540-15043-9, pp 379-393.

[6]. De Crécy-Lagard, V., El Yacoubi, B., de la Garza, R. D., Noiriel, A., and Hanson, A. D., 2007, Comparative genomics of bacterial and plant folate synthesis and salvage : predictions and validations, BMC Genomics, $8: 245$.

[7]. Hauser, P. M. and Macreadie, I. G., 2006, Isolation of the Pneumonic carinii dihydrofolate gene and functional compllementation in Saccharomyces cerevisiae, Federation of European Microbiological Societies Lett 256, 244 250, Published by Blackwell Publishing Ltd.

[8]. Malbasa, et al., 2008. Comparison of the product of kombucha fermentation on sucrose and molasses. Food Chem 106 (3), 1039-1045.

[9]. Quilivan, E.P., S. Roje, G. Basset, Y. Shahar-Hill, J.F. Gregory, and A.D. Hanson. 2003. The Folate precursor $\rho$ aminobenzoate is reversible converted to is glucose ester in the plant cytosol. J. Bio. Chem. 278:20731-20737.

[10]. Susilowati, A, Aspiyanto, Maryati, Y, Melanine, H., Lotulung, P.D. 2017b. Recovering Folic Acid and Its Identification on mixde pastes of tempeh and fermented vehetale as natural source of folic acid. Paper of the 2 nd International Conference on Engineering and Technology for
Sustainable Development, Faculty of Industrial Technology University of Islam Indonesia join with Kansai University, Universiti Teknologi MARA, University of gajah Mada and SIIT (Srindhorn International of Technology), Yogyakarta, Indonesia, 13-14th, September, 2017.

[11]. Rooney, L.W \& Serna-Salvidar, S.O. 1987. Food uses whole corn and dry milled factions. Pp. 399-429 In, Corn: Chemistry and Technology (S.A. Watson and Ramsted, P.E, ed) . ACCC.St. Paul, MN.

[12]. Susilowati, A., Iskandar, Y. M, Melanie, H., Maryati, Y., Lotulung, 2016, Pengembangan Konsentrat Sayuran Hijau dan Kacangkacangan Terfermentasi pada jagung (Zea mays L.) pramasak sebagai sumber asam Folat untuk formula pangan pintar. Laporan Hasil Penelitian, Program Tematik, Kedeputian IPT, Tahun Anggaran 2015, Pusat Penelitian Kimia - LIPI, PUSPIPTEK, Serpong, Tangerang Selatan.

[13]. Lowry, O. H., Rosebrough, N. J., Farr, A. L., Randall, R. J. 1951. Protein measurement with Folin phenol reagent. J. Biol. Chem. 193 (1), 265 - 276. PMID 14907713.

[14]. Anonymous. 2016. Official Methods of Analysis of the Association of Analytical Chemistry, A. O. A. C, Inc., Washington D.C.

[15]. Ruengsitagoon, W. \& Hattanat, N. 2012, Simple spectrophotometric method for determination of folic acid, The $4^{\text {th }}$ Annual Northeast Pharmacy Research Conference, Thailand, 2012.

[16]. Eichhorn, P. and Knepper, T. P., 2001, Electrospray ionization mass spectrometric studies on the amphoteric surfactant cocamidopropylbetaine, Journal of Mass Spectrum, June : 36 (6), 677 - 684. DOI : 10.1002/jms. 170.

[17]. Syarief, R, Astuti, M, Hermanianto, J, Hariyadi, P, Wiraatmaja, S, Suliantari, Dahrulsyah, Suyatna, NE, Saragih,YP, Arisasmita, JH. 1999. Wacana Tempe Indonesia, Universitas Katolik Widya Mandala, Surabaya.

[18]. McKenzie, S.B. 1999. Megaloblastic and Nonmegaloblastic Macrocytic Anemias. di dalam Textbook of Hematology, Edisi 2. Baltimore, Williams adn Wilkins. Pg. 179199. 
Proses Emulsifikasi dan Pengeringan Pasta Campuran Sumber Asam Folat Alami dan Identifikasinya dalam Perolehan Serbuk Suplemen untuk Wanita Hamil

[19]. Nugraha, T., Susilowati, A., Aspiyanto, Lotulung, P.D., Maryati,Y. 2017. Characterization of Biomasses, Concentrate, and Permeates of Dried Powder of Kombucha Fermentation of Spinach (Amaranthus sp.) and Broccoli (Brassica oleracea) with Membrane Microfiltration and Freeze Drying Techniques for natural Sources of Folic Acid. 2017. Proceedings of the 3 rd International Symposium on Applied Chemistry 2017, AIP Conference Proceedings, Volume 1904, AIP Publishing, Melville, New York, 2017, ISBN 978-07354-1594-2, ISSN, 0094-243X, Jakarta, Indonesia, 23-24 October 2017.
[20]. Delchier, N., Ringling, C., Maingonnat, J. F., Rychlik, M., Renard, C. M. G. C. 2014. Mechanisms of folate losses during processing : diffusion vs heat degradation. Food Chem., 157 : pp.439 - 47. Accessed at 25 April 2017.

[21]. Fleche, G. 1985. Chemical Modification and Degradation of Starch in G.MA. Van Beynum and J. A. Rolls (eds.), Marcel Dekker Inc., New York, U. S. A.

[22]. Nagodawithana, T., 1993. Enzymes Associate with Savory Flavor Enhancement, di dalam Enzymes in Food Processing, Tilak Nagodawithana \& Gerald Reed, Academic Press, Inc, San Diego, California 921014311. 